\title{
Cross-cultural adaptation to Brazilian Portuguese of the Dementia Knowledge Assessment Tool Version Two: DKAT2
}

\author{
Adaptação transcultural para o português brasileiro da Dementia Knowledge Assesment \\ Tool Version Two: DKAT2
}

Marcelo Piovezan', Hélio Amante Miot', Miriane Garuzi', Alessandro Ferrari Jacinto'

\begin{abstract}
The Dementia Knowledge Assessment Tool Version Two (DKAT2) was developed to measure caregivers' knowledge about the trajectory of dementia and assess changes in the knowledge before and after educational programs. The DKAT2 is a 21-item tool with questions about several aspects of dementia. The possible answers for each question are "yes", "no" or "don't know". The maximum score is 21. Objective: The aim of the study was to cross-culturally adapt the DKAT2 to Brazilian Portuguese. Methods: The essential steps to cross-culturally adapt were conducted and the final version administered to 30 caregivers of older people with dementia, sampled by convenience. Results: In the sample assessed, the mean age was 55.7 ( \pm 12.5 ) years, $93.3 \%$ were female, $56.7 \%$ were sons/daughters and $23.3 \%$ were spouses of the older adults with dementia. The mean time caring for the elder was 4.7 ( \pm 3.3 ) years and $70 \%$ of the caregivers had some level of burden. The mean age of the older people was 82.4 ( \pm 6.7 ) years, 19 (63.3\%) had a diagnosis of Alzheimer's disease, $100 \%$ were dependent for instrumental activities of daily living and $70 \%$ had some degree of dependence for basic activities of daily living. The mean score for the caregivers' knowledge level was 15.0 ( \pm 2.5 ) correct answers. Conclusions: The Brazilian Portuguese version was developed and the final version is suitable for use in Brazil.
\end{abstract}

Keywords: aged; caregivers; dementia; knowledge.

\section{RESUMO}

"Dementia Knowledge Assessment Tool Version Two" (DKAT2) foi desenvolvido para medir o conhecimento de cuidadores sobre a trajetória da demência e avaliar as mudanças no conhecimento antes e depois de programas educacionais. DKAT2 é uma ferramenta de 21 itens com perguntas sobre vários aspectos da demência. As respostas possíveis para cada pergunta são "sim”, "não" ou “não sei”. A pontuação máxima é de 21. Objetivo: Adaptar culturalmente o DKAT2 ao português brasileiro. Métodos: Foram realizadas as etapas essenciais para a adaptação cultural e a versão final foi administrada a uma amostra de conveniência de 30 cuidadores de idosos com demência. Resultados: A idade média dos cuidadores foi de 55,7 ( \pm 12,5) anos, 93,3\% eram do sexo feminino, 56,7\% eram filhos e 23,3\% cônjuges dos idosos com demência. 0 tempo médio de cuidado ao idoso foi de 4,7 ( $\pm 3,3)$ anos e 70,0\% dos cuidadores mostraram algum nível de sobrecarga. A média de idade dos idosos com demência foi de 82,4 $( \pm 6,7)$ anos, 19 (63,3\%) tiveram diagnóstico de doença de Alzheimer, 100\% eram dependentes nas atividades instrumentais da vida diária e 70,0\% tinham algum grau de dependência nas atividades básicas de vida diária. 0 escore médio do nível de conhecimento dos cuidadores foi de 15,0 $( \pm 2,5)$ respostas corretas. Conclusões: A versão em português do Brasil foi obtida e mostrou-se adequada para uso no Brasil.

Palavras-chave: idoso; cuidadores; demência; conhecimento.

Population aging is associated with an increase in the prevalence of dementia, the rate of which doubles every five years from the age of $60^{1}$. The prevalence of dementia in Latin America is $7.1 \%$, similar to that found in many other studies worldwide ${ }^{2,3}$.

Dementia is associated with functional dependency. The symptoms of dementia affect the quality of life of both patients and their caregivers ${ }^{4,5}$.
Lack of knowledge about dementia is associated with unnecessary and stressful interventions such as catheter feeding, hospital and emergency room transfers, and intravenous treatment, especially at advanced stages of the disease ${ }^{6}$.

There are instruments available to evaluate knowledge and attitudes towards dementia among health professionals, mainly doctors and nurses. However, such instruments for caregivers are scarce ${ }^{7}$.

\footnotetext{
${ }^{1}$ Universidade Estadual Paulista, Faculdade de Medicina de Botucatu, Botucatu SP, Brasil.

Correspondence: Alessandro Ferrari Jacinto; Rua Carlos Guadanini, 2179; 18610-120 Botucatu SP, Brasil; E-mail: alessandrojacinto@uol.com.br Acknowledgments: We thank the caregivers of older people with dementia who kindly agreed to participate in this study. Conflict of interest: There is no conflict of interest to declare.

Support: Coordenação de Aperfeiçoamento de Pessoal de Nivel Superior (CAPES) - Masters Scholarship.

Received 16 February 2018; Received in final form 29 March 2018; Accepted 09 April 2018.
} 
Toye et al. ${ }^{7}$, from 2006 to 2008, developed the Dementia Knowledge Assessment Tool Version One (DKAT1), which measures knowledge about the trajectory of dementia and assesses changes in the knowledge of participants before and after educational programs. It was first developed for formal caregivers (meaning people employed to provide care) and, after testing, it was improved for use in both formal and informal caregivers. In 2009, the second version (DKAT2) was developed by the same authors.

The DKAT2 has 21 statements addressing several areas of dementia knowledge, encompassing features of Alzheimer's disease and vascular dementia, behavioral, emotional, physiological, functional and sensory symptoms of dementias, as well as symptoms that are not necessarily associated with dementias. There are three possible answers for each statement: "yes", "no" and "don't know." Answers are scored as 1 if correct and 0 if incorrect or "don't know". The higher the final score, the higher the knowledge about dementia.

This study aimed to develop the Brazilian Portuguese version of the Dementia Knowledge Assessment Tool Version 2.

\section{METHODS}

The study was conducted between April 2016 and May 2017 at the Inpatient Geriatric Clinic of the Botucatu Medical School, São Paulo State University.

The Brazilian Portuguese version was developed as below:

A) Authorization for the study given by the author of the instrument.

B) Translation from English into Portuguese as spoken in Brazil by two individuals whose native language was Portuguese and who were fluent in English, where one of the translators was aware of the study.

$\mathrm{C})$ Consensus between the researcher (MP) and his advisor (AFJ) in order to obtain a version based on the translations carried out in item B.

D) Back translation (Portuguese into English) of the version from item $\mathrm{C}$ by two individuals unaware of the study whose native language was English and who were fluent in Portuguese spoken in Brazil.

E) Obtaining a final version of the two versions from item $D$.

F) Analysis of the whole process (items A to E) and submission of the final version to the author of the instrument for its appraisal.

G) Application of the final version to caregivers of the older people with dementia.

Thirty caregivers, to whom the Brazilian version of the DKAT2 was administered, were interviewed at the Geriatric Clinic of the Botucatu Medical School, São Paulo State University. For inclusion, caregivers had to have given care for at least one year on a regular basis. The caregivers were assessed before or after the medical appointment of the elderly person with dementia. The patient's diagnosis of dementia was confirmed by the researcher through checking of the medical registration. None of the caregivers refused to participate in the study.

For the evaluation of the caregivers, the following instruments were administered: sociodemographic questionnaire, the DKAT2 ${ }^{8}$, Functional Activities Questionnaire (to evaluate the elderly patient's instrumental activities of daily living $)^{9}$, Katz Index (to evaluate the patient's basic activities of daily living) ${ }^{10}$, Zarit Burden Interview (to evaluate caregiver's burden) ${ }^{11}$ and the Patient Health Questionnaire-2 (to screen the caregiver for depression) ${ }^{12}$.

All caregivers signed the informed consent form before the interview. The study was approved by the Ethics Committee of the Botucatu Medical School, São Paulo State University (number: 50028115.6.0000.5411).

The categorical variables were expressed as raw numbers and percentile values. Continuous variables, according to their normal distribution or otherwise, were expressed as measures of central tendency: means and standard deviations or medians and interquartile ranges ${ }^{13}$.

The relation among DKAT2 scores and the other variables was explored spatially by multiple correspondence analysis, where the association of categories is represented as a spatial proximity ${ }^{14}$.

\section{RESULTS}

Figure 1 shows the original Australian version of the DKAT2 7 . Figure 2 shows the Brazilian version of the DKAT2.

Thirty caregivers with a mean age of $55.7( \pm 12.5)$ years were interviewed. The mean number of correct answers on the DKAT2 was $15( \pm 2.5)$ and the mean caring time was 4.7 ( \pm 3.3 ) years; $93.3 \%$ were female, $56.7 \%$ were sons/daughters, $70 \%$ showed some degree of burden and $23.3 \%$ screened positively for depression.

Regarding the older adults assessed, the mean age was $82.4( \pm 6.7)$ years, $19(63.3 \%)$ had a diagnosis of Alzheimer's disease, five (16.7\%) vascular dementia and six (20\%) other types of dementia. The mean Functional Activities Questionnaire score was $22.3( \pm 7.7)$, indicating that $100 \%$ of the older adults were dependent for instrumental activities of daily living and $70 \%$ had some degree of dependence for basic activities of daily living according to the Katz Index.

The questionnaire was considered easy to fill in, as all participants completed it in less than 10 minutes.

Figure 3 shows the perceptual map from multiple correspondence analyses, accounting for about $30 \%$ of overall variance of the model. The DKAT2 scores were categorized in three levels (11-13; 14-16; 17-20). Especially, higher DKAT2 scores were in proximity to being diagnosed with Alzheimer's disease, higher Katz Index scores and lower PHQ-2 scores. Lower DKAT2 scores were in proximity to higher Zarit Burden Interview scores and lower Functional Activities Questionnaire (Pfeffer) scores. 


\begin{tabular}{|c|c|c|c|}
\hline Statements & Yes & No & $\begin{array}{l}\text { Don't } \\
\text { Know }\end{array}$ \\
\hline 1. Dementia occurs because of changes in the brain. & 1 & 0 & 0 \\
\hline 2. Brain changes causing dementia are often progressive. & 1 & 0 & 0 \\
\hline 3. Alzheimer's disease is the main cause of dementia. & 1 & 0 & 0 \\
\hline 4. Blood vessel disease can also cause dementia. & 1 & 0 & 0 \\
\hline 5. Confusion in an older person is almost always due to dementia. & 0 & 1 & 0 \\
\hline 6. Only older adults develop dementia. & 0 & 1 & 0 \\
\hline 7. Knowing the likely cause of dementia can help to predict its progression. & 1 & 0 & 0 \\
\hline 8. Incontinence always occurs in the early stages of dementia. & 0 & 1 & 0 \\
\hline 9. Dementia is likely to limit life expectancy. & 1 & 0 & 0 \\
\hline 10. When a person has late stage dementia, families can help others to understand that person's needs. & 1 & 0 & 0 \\
\hline 11. People who have dementia may develop problems with visual perception (understanding or recognising what they see). & 1 & 0 & 0 \\
\hline 12. Sudden increases in confusion are characteristic of dementia. & 0 & 1 & 0 \\
\hline $\begin{array}{l}\text { 13. Uncharacteristic distressing behaviours may occur in people who have dementia (e.g., aggressive behaviour } \\
\text { in a gentle person). }\end{array}$ & 1 & 0 & 0 \\
\hline 14. Difficulty swallowing occurs in late stage dementia. & 1 & 0 & 0 \\
\hline 15. Movement (e.g., walking, moving in a bed or chair) is limited in late stage dementia. & 1 & 0 & 0 \\
\hline $\begin{array}{l}\text { 16. Changing the environment (e.g., putting on a CD, opening or closing the blinds) will make no difference to a } \\
\text { person who has dementia. }\end{array}$ & 0 & 1 & 0 \\
\hline 17. When a person who has dementia is distressed, it may help to talk to them about their feelings. & 1 & 0 & 0 \\
\hline 18. It is important to always correct a person who has dementia when they are confused. & 0 & 1 & 0 \\
\hline 19. A person who has dementia can often be supported to make choices (e.g., what clothes to wear). & 1 & 0 & 0 \\
\hline 20. It is impossible to tell if a person who is in the later stages of dementia is in pain. & 0 & 1 & 0 \\
\hline 21. Exercise can sometimes be of benefit to people who have dementia. & 1 & 0 & 0 \\
\hline
\end{tabular}

Figure 1. Original Australian version of the DKAT2.?

\begin{tabular}{|c|c|c|c|}
\hline Afirmações & Sim & Não & $\begin{array}{l}\text { Não } \\
\text { sei }\end{array}$ \\
\hline 1. A demência ocorre devido a mudanças no cérebro. & 1 & 0 & 0 \\
\hline 2. As mudanças no cérebro que causam demência geralmente são progressivas. & 1 & 0 & 0 \\
\hline 3. A Doença de Alzheimer é a principal causa de demência. & 1 & 0 & 0 \\
\hline 4. Doenças vasculares também podem causar demência. & 1 & 0 & 0 \\
\hline 5. Confusão mental em idosos quase sempre é causada por demência. & 0 & 1 & 0 \\
\hline 6. Apenas idosos desenvolvem demência. & 0 & 1 & 0 \\
\hline 7. Conhecer a causa provável de demência pode ajudar a entender sua progressão. & 1 & 0 & 0 \\
\hline 8. Falta de controle da urina e/ou fezes sempre ocorre nos estágios inicias da demência. & 0 & 1 & 0 \\
\hline 9. A demência tende a limitar a expectativa de vida. & 1 & 0 & 0 \\
\hline $\begin{array}{l}\text { 10. Quando uma pessoa se encontra em estágio avançado de demência, os familiares podem ajudar outras } \\
\text { pessoas a compreender as necessidades do paciente. }\end{array}$ & 1 & 0 & 0 \\
\hline $\begin{array}{l}\text { 11. As pessoas com demência podem desenvolver problemas de percepção visual (ex. compreender ou } \\
\text { reconhecer o que veem). }\end{array}$ & 1 & 0 & 0 \\
\hline 12. Crises repentinas de confusão mental são características da demência. & 0 & 1 & 0 \\
\hline $\begin{array}{l}\text { 13. Presença de comportamentos não característicos da pessoa pode ocorrer em pacientes com demência (ex. } \\
\text { comportamento agressivo por parte de alguém que sempre foi gentil). }\end{array}$ & 1 & 0 & 0 \\
\hline 14. Dificuldade para engolir surge em estágios avançados da demência. & 1 & 0 & 0 \\
\hline $\begin{array}{l}\text { 15. Mobilidade (ex. caminhar, movimentar-se na cama ou cadeira) fica limitada nos estágios avançados da } \\
\text { demência. }\end{array}$ & 1 & 0 & 0 \\
\hline $\begin{array}{l}\text { 16. Mudanças no ambiente não farão diferença para uma pessoa com demência (ex. por um CD para tocar, abrir } \\
\text { ou fechar as cortinas). }\end{array}$ & 0 & 1 & 0 \\
\hline 17. Quando a pessoa com demência está angustiada, conversar sobre seus sentimentos pode ajudar. & 1 & 0 & 0 \\
\hline 18. É importante sempre corrigir a pessoa com demência quando ela estiver confusa. & 0 & 1 & 0 \\
\hline 19. Uma pessoa com demência geralmente pode ser apoiada a fazer escolhas (ex. a escolher o que vestir etc.). & 1 & 0 & 0 \\
\hline 20. É impossível dizer se uma pessoa em estágio avançado de demência está com dor. & 0 & 1 & 0 \\
\hline 21. Exercícios físicos, às vezes, podem ser benéficos a pessoas com demência. & 1 & 0 & 0 \\
\hline
\end{tabular}

Figure 2. Brazilian version of the DKAT2. 


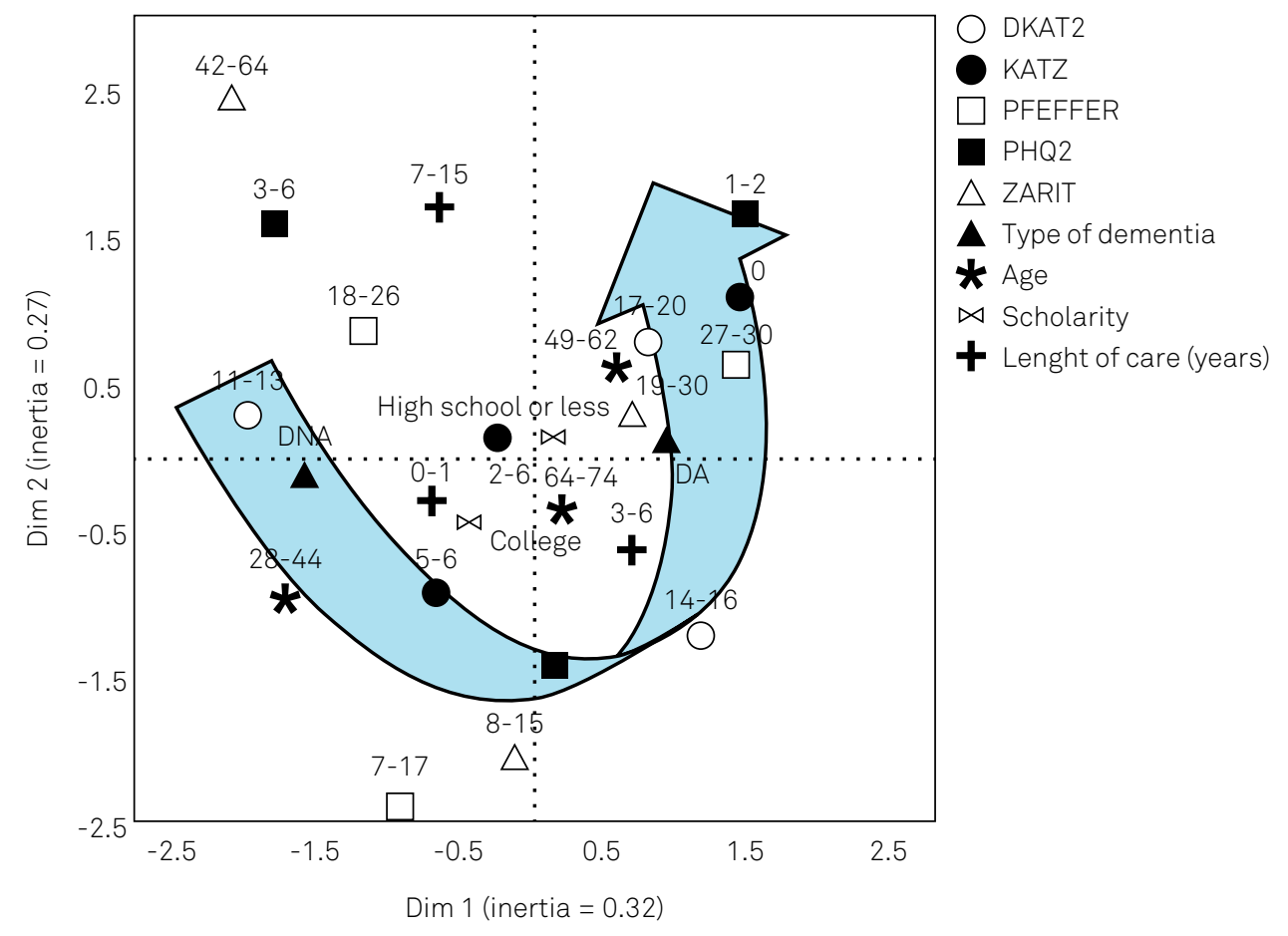

Figure 3. Perceptual map from multiple correspondence analyses

\section{DISCUSSION}

The cross-cultural adaptation process of the DKAT2 to Brazilian Portuguese revealed some particular adaptations during translation and back translation phases of the instrument, although no substantial differences in the essential meaning were observed.

The present study showed that $93.3 \%$ of the caregivers were female, $56.7 \%$ were daughters or sons, and $23.3 \%$ spouses of the older adults with dementia, a finding in line with other studies ${ }^{15,16,17}$.

Previous studies involving caregivers of patients with dementia or mental disorders have found that the mean age of caregivers was 56 years, similar to that found in the present study ${ }^{6,11,18}$.

Regarding the emotional state of the caregivers interviewed, $70 \%$ showed some level of burden. Previous studies ${ }^{4,17}$ have found that older people's dependence for activities of daily living affects caregivers' quality of life and, when the caregiver does not know how to deal with the tasks of caring, the stress and burden generated by it can affect their physical and emotional health.
The mean age of the older adults with dementia in the present study was 82.4 years, which is in accordance with the projections of the Brazilian Institute of Geography and Statistics ${ }^{19}$.

In this study, dementia due to Alzheimer's disease was the most prevalent type (63.3\%), confirming the information previously stated on the most common cause of dementia'; all of the older adults with dementia were dependent for instrumental activities of daily living and $70 \%$ had some degree of dependence for basic activities of daily living. These data confirm the progressive impairment of the individual's functional abilities caused by dementia ${ }^{17}$.

On the multivariable analysis, caregivers' lower depression scores were related to higher knowledge scores, which leads to the hypothesis that efforts in the promotion of mental health can result in better performance of care.

Lower knowledge scores were related to the older person having been diagnosed with non-Alzheimer's disease. This finding can be explained by the fact that the media content on dementia is more often associated with Alzheimer's disease.

A validation study of this construct is warranted.

\section{References}

1. Lopes MA, Bottino CM. [Prevalence of dementia in several regions of the world: analysis of epidemiologic studies from 1994 to 2000]. Arq Neuropsiquiatr. 2002 Mar;60(1):61-9. Protuguese. https://doi.org/10.1590/S0004-282X2002000100012

2. Pot AM, Petrea I. Bupa/ADI: Melhoria mundial do tratamento da demência: ideias e conselhos sobre o desenvolvimento e implementação de um Plano Nacional de Demência. Londres: Bupa/ADI; 2013.

3. Nitrini R, Bottino CM, Albala C, Custodio Capuñay NS, Ketzoian C, Llibre Rodriguez JJ et al. Prevalence of dementia in Latin America: a collaborative study of population-based cohorts. Int Psychogeriatr. 2009 Aug;21(4):622-30. https://doi.org/10.1017/\$1041610209009430 
4. Novelli MM, Caramelli P. The influence of neuropsychiatric and functional changes on quality of life in Alzheimer's disease. Dement Neuropsychol. 2010 Jan-Mar;4(1):47-53. https://doi.org/10.1590/S1980-57642010DN40100008

5. Chang YJ, Kwon YC, Lee WJ, Do YR, Seok LK, Kim HT et al. Burdens, needs and satisfaction of terminal cancer patients and their caregivers. Asian Pac J Cancer Prev. 2013;14(1):209-16. https://doi.org/10.7314/APJCP.2013.14.1.209

6. Robinson A, Eccleston C, Annear M, Elliott KE, Andrews S, Stirling C et al. Who knows, who cares? Dementia knowledge among nurses, care workers, and family members of people living with dementia.J Palliat Care. 2014;30(3):158-65.

7. Toye C, Lester L, Popescu A, Mclnerney F, Andrews S, Robinson AL. Dementia Knowledge Assessment Tool Version Two: development of a tool to inform preparation for care planning and delivery in families and care staff. Dementia. 2014 Mar;13(2):248-56. https://doi.org/10.1177/1471301212471960

8. Canino G, Bravo M. The adaptation and testing of diagnostic and outcome measures for cross-cultural research. Int Rev Psychiatry. 1994;6(4):281-6. https://doi.org/10.3109/09540269409023267

9. Pfeffer RI, Kurosaki TT, Harrah CH Jr, Chance JM, Filos S. Measurement of functional activities in older adults in the community. J Gerontol. 1982 May;37(3):323-9. https://doi.org/10.1093/geronj/37.3.323

10. Katz S, Ford AB, Moskowitz RW, Jackson BA, Jaffe MW. Studies of illness in the aged: the index of ADL: a standardized measure of biological and psychosocial function. JAMA. 1963 Sep;185(12):914-9. https://doi.org/10.1001/jama.1963.03060120024016

11. Scazufca M. Versão brasileira da escala Burden Interview para avaliação de sobrecarga em cuidadores de indivíduos com doenças mentais. Rev Bras Psiquiatr. 2002 Mar;24(1):12-7. https://doi.org/10.1590/S1516-44462002000100006.
12. Kroenke K, Spitzer RL, Williams JB. The Patient Health Questionnaire-2: validity of a two-item depression screener. Med Care. 2003 Nov;41(11):1284-92. https://doi.org/10.1097/01.MLR.0000093487.78664.3C

13. Miot HA. Assessing normality of data in clinical and experimental trials. J Vasc Bras. 2017;16(2):88-91. https://doi.org/10.1590/1677-5449.041117

14. Sourial N, Wolfson C, Zhu B, Quail J, Fletcher J, Karunananthan $S$ et al. Correspondence analysis is a useful tool to uncover the relationships among categorical variables. J Clin Epidemiol. 2010 Jun;63(6):638-46. https://doi.org/10.1016/j.jclinepi.2009.08.008

15. Neri AL, Sommerhalder C. As várias faces do cuidador e do bem-estar do cuidador. In: Neri AL. Cuidar de idosos no contexto da família: questões psicológicas e sociais. 3a ed. Campinas, SP: Alínea; 2012.

16. Hosseinpoor AR, Bergen N, Chatterji S. Socio-demographic determinants of caregiving in older adults of low- and middle-income countries. Age Ageing. 2013 May;42(3):330-8. https://doi.org/10.1093/ageing/afs196

17. Toribio-Díaz ME, Medrano-Martínez V, Moltó-Jordá JM, BeltránBlasco I. Characteristics of informal caregivers of patients with dementia in Alicante province. Neurología. 2013 Mar;28(2):95-102. https://doi.org/10.1016/j.nrl.2012.03.010

18. Taub A, Andreoli S, Bertolucci PH. Dementia caregiver burden: reliability of the Brazilian version of the Zarit caregiver burden interview. Cad Saúde Pública. 2004Mar-Apr;20(2):372-6. https://doi.org/10.1590/S0102-311X2004000200004

19. Instituto Brasileiro de Geografia e Estatística - IBGE. Em 2013, esperança de vida ao nascer era de 74,9 anos. Rio de Janeiro: Instituto Brasileiro de Geografia e Estatística; 2014 [access 2018 Jan 30]. Available from: https://agenciadenoticias.ibge.gov.br/2013agencia-de-noticias/releases/14712-asi-em-2013-esperanca-devida-ao-nascer-era-de-749-anos.html 